\title{
Molecular cloning and pharmacological characterization of porcine melanocortin-3 receptor
}

\author{
Zhen-Chuan Fan, James L Sartin and Ya-Xiong Tao \\ Department of Anatomy, Physiology and Pharmacology, College of Veterinary Medicine, Auburn University, Auburn, Alabama 36849-5519, USA \\ (Correspondence should be addressed to Y-X Tao; Email: taoyaxi@vetmed.auburn.edu)
}

\begin{abstract}
Mouse gene targeting studies revealed that the melanocortin-3 receptor (MC3R) affected feeding efficiency and fat storage in mice. The functions of the MC3R in other mammalian species remain to be investigated. We are interested in exploring the functions of the porcine MC3R (pMC3R) in regulating fat storage because of the economical importance of swine industry. Although nucleotide sequences of MC3Rs from several species have been reported, pMC3R had not been cloned and sequenced. We reported herein the molecular cloning and pharmacological analysis of the pMC3R. Sequence analysis revealed that pMC3R was highly homologous $(>80 \%)$ at nucleotide and amino acid sequences to human, rat, and mouse MC3Rs. With human MC3R (hMC3R) as a control, the binding and signaling properties of $\mathrm{pMC} 3 \mathrm{R}$ were investigated using several agonists
\end{abstract}

including $\alpha$ - and $\gamma$-melanocyte-stimulating hormone $(\alpha-$ and $\gamma-\mathrm{MSH})$, D-Trp ${ }^{8}-\gamma-\mathrm{MSH}$, and $\left[\mathrm{Nle}^{4}-\mathrm{D}-\mathrm{Phe}^{7}\right]-\mathrm{MSH}$ (NDP$\mathrm{MSH}$ ) and the natural antagonist agouti-related protein (AgRP). The results showed that pMC3R bound NDP-MSH with the highest affinity followed by D-Trp ${ }^{8}-\gamma \mathrm{MSH}, \gamma-$, and $\alpha-\mathrm{MSH}$. The same ranking was also found for $\mathrm{hMC} 3 \mathrm{R}$, although $\mathrm{pMC} 3 \mathrm{R}$ had two- to ninefold higher affinities for these ligands. Both $\mathrm{pMC} 3 \mathrm{R}$ and hMC3R bound AgRP with high affinity. D-Trp ${ }^{8}-\gamma-\mathrm{MSH}$ was the most potent agonist to stimulate cAMP generation followed by NDP-, $\alpha-$, and $\gamma-\mathrm{MSH}$. This ranking was the same as that of hMC3R. The availability of pMC3R and its pharmacological characteristics will facilitate the investigation of $\mathrm{pMC} 3 \mathrm{R}$ in regulating food intake and fat storage.

Journal of Endocrinology (2008) 196, 139-148

\section{Introduction}

Melanocortins including $\alpha-, \beta$-, and $\gamma$-melanocyte-stimulating hormones $(\alpha-, \beta-$, and $\gamma-\mathrm{MSH})$ and adrenocorticotropic hormone $(\mathrm{ACTH})$ are short peptide hormones derived from pro-opiomelanocortin (POMC) through tissue-specific posttranslational processing (Smith \& Funder 1988). The melanocortin receptors (MCRs) are members of rhodopsin-like (family A) G-protein-coupled receptors (GPCRs). They are expressed on the cell surface, predicted to have seven transmembrane domains (TMDs) connected by alternating extracellular and intracellular loops, with the $\mathrm{N}$-terminus lying on the outside of the cell and the C-terminus locating on the inside of the cell. Once bound to MCRs, melanocortins induce conformational changes in MCRs facilitating their coupling to and activation of the stimulatory G-protein, Gs. Activated Gs enhances adenylyl cyclase activity resulting in increased production of the intracellular second messenger cAMP triggering downstream signal transduction pathways (Gantz \& Fong 2003). Agouti and agouti-related protein (AgRP) are the endogenous antagonists of the MCRs. So far, five MCRs have been cloned, named MC1R to MC5R according to the sequence of their cloning (Gantz \& Fong 2003). Of the MCRs, MC3R and MC4R are the main subtypes expressed in the brain. They are expressed in the hypothalamic paraventricular nucleus and arcuate nucleus as well as in other brain regions including the cortex, thalamus, and hippocampus (Gantz et al. 1993a,b, Roselli-Rehfuss et al. 1993, Mountjoy et al. 1994). The MC3R is also expressed in the placenta and gut (Gantz et al. 1993a) and immune cells such as macrophages (Getting et al. 1999).

Although both the MC3R and the MC4R are involved in the central control of energy homeostasis, it is clear that the MC4R primarily regulates food intake and energy expenditure (reviewed in Cone 2005). On the other hand, the MC3R does not regulate food intake. MC3R knockout mice did not have hyperphagia and obesity; they had similar or even decreased levels of food intake and normal energy expenditure as compared with their wild-type littermates (Butler et al. 2000, Chen et al. 2000). Of particular interest was the observation that these mice have increased fat mass and decreased lean mass. Therefore, the MC3R is involved in regulation of feeding efficiency and fat storage. When compared with MC3R or MC4R single gene knockout mice, mice lacking both MC3R and MC4R developed exacerbated obesity, suggesting that the two central MCRs regulate different aspects of energy homeostasis (Chen et al. 2000). However, a recent gene knockout study performed with an obesity-resistant mice strain (Black Swiss 129) indicated that MC3R single gene knockout mice developed 
a comparable degree of increased adiposity as the MC4R knockout mice (Zhang et al. 2005) suggesting that the MC3R might also be involved in regulating food intake and energy expenditure. A potential pathway that the MC3R might regulate food intake is by releasing the inhibitory effect of the MC3R on POMC neurons (Marks et al. 2006).

To begin to understand what role(s) the MC3R might play in regulating fat storage and energy homeostasis in the pig, we report herein the molecular cloning and pharmacological characterization of the pMC3R. For the pharmacological characterizations, we tested several ligands including the endogenous agonists $\alpha$ - and $\gamma-\mathrm{MSH}$, a superpotent agonist specific for the MC3R, D-Trp ${ }^{8}-\gamma-\mathrm{MSH}$ (Grieco et al. 2000), and a superpotent analog of $\boldsymbol{\alpha}-\mathrm{MSH}$ specific for all MCRs except MC2R (the ACTH receptor), [Nle $\left.{ }^{4}-\mathrm{D}-\mathrm{Phe}{ }^{7}\right]-\mathrm{MSH}$ (NDPMSH; Sawyer et al. 1980). We also tested the binding of the cloned receptor to the natural antagonist of the MC3/4R, AgRP.

\section{Materials and Methods}

\section{Plasmid and peptides}

Human MC3R cDNA inserted in a mammalian expression vector, pcDNA3.1, was kindly provided by Dr Ira Gantz (University of Michigan, Ann Arbor, MI, USA). $\alpha_{-}, \gamma-$, and NDP-MSH were purchased from Phoenix Pharmaceuticals (Belmont, CA, USA). D-Trp ${ }^{8}-\gamma-\mathrm{MSH}$ and AgRP (86-132) were obtained from Peptides International Inc. (Louisville, KY, USA). ${ }^{125}$ I-iodinated NDP-MSH was purchased from Peptide Radioiodination Service Center, The University of Mississippi (University, MS, USA).

\section{Molecular cloning of porcine MC3R}

Sequence analysis performed with DNAman program (Lynnon Corp., Quebec, Canada) suggested that the putative coding region of the $p M C 3 R$ gene consists of a single exon of $960 \mathrm{bp}$. Thus, the pMC3R coding region was amplified directly from porcine genomic DNA (Novagen, San Diego, CA, USA) using a primer pair (sense primer, $5^{\prime}$-AAGAATTCATGAATGCTTCGTGCTGC- $3^{\prime}$ and antisense primer, $5^{\prime}$-CCTCTAGAGCCTCCTACCCCAGGTTC- $3^{\prime}$ ) designed based on the published pig genomic DNA sequence from clone CH242-163M14 on chromosome 17 (GenBank accession no. CR 956393). To facilitate the cloning, EcoRI and XbaI sites (underlined) were incorporated in sense and antisense primers respectively. The PCR was performed in a $50 \mu \mathrm{l}$ mixture containing $100 \mathrm{ng}$ porcine genomic DNA, $0 \cdot 25 \mathrm{mMdNTPs}, 0 \cdot 4 \mu \mathrm{M}$ of each of the primers, $1 \times$ pfu Turbo DNA polymerase buffer, $1.5 \mathrm{mM}$ $\mathrm{MgCl}_{2}$, and $2 \cdot 5 \mathrm{U}$ pfu Turbo DNA polymerase (Stratagene, La Jolla, CA, USA) with the following parameters: $2 \mathrm{~min}$ at $95^{\circ} \mathrm{C}$ for one cycle and $1 \mathrm{~min}$ at $95{ }^{\circ} \mathrm{C}, 45 \mathrm{~s}$ at $56^{\circ} \mathrm{C}$, and 90 s at $72{ }^{\circ} \mathrm{C}$ for 45 cycles followed by a final cycle at $72^{\circ} \mathrm{C}$ for $10 \mathrm{~min}$. Subsequently, the $960 \mathrm{bp}$ PCR fragment was visualized after electrophoresis with ethidium bromide using a $1 \%$ agarose gel, purified with Qiagen PCR purification kit (Qiagen), double digested with EcoRI and XbaI (New England Biolabs, Beverly, MA, USA). The EcoRI-XbaI DNA fragment was purified again with Qiagen PCR purification kit and then cloned into the expression vector pcDNA3.1(+) using T4 DNA ligase (Roche) according to the manufacturer's protocol. The nucleotide sequence of the cloned $p M C 3 R$ gene was determined by sequencing three independent plasmids and deposited in NCBI GenBank with an accession number EU091085. Plasmids were prepared with Qiagen plasmid maxi kit for transfection of human embryonic kidney (HEK) 293T cells as described below.

\section{Homology and phylogenetic analysis of pMC3R}

Homology and phylogenetic analyses at nucleotide and amino acid levels were performed between different species including porcine, human, mouse, and rat using DNAman program and MacVector 8.0 (Accelrys Software Inc., San Diego, CA, USA) respectively, according to the manufacturer's protocols.

\section{Transient expression of plasmids}

Transient expression of plasmids was performed in HEK293T cells (American Type Culture Collection, Manassas, VA, USA). HEK293T cells were cultured at $5 \% \mathrm{CO}_{2}$ in Dulbecco's modified Eagle's medium supplemented with $10 \%$ newborn calf serum, $10 \mathrm{mM}$ HEPES, $100 \mathrm{units} / \mathrm{ml}$ penicillin, and $100 \mu \mathrm{g} / \mathrm{ml}$ streptomycin (all from Invitrogen). Cells were plated on gelatincoated $35 \mathrm{~mm}$ six-well plates (Corning, Corning, NY, USA) or on gelatin-coated $100 \mathrm{~mm}$ plates. Transient transfection was performed using the calcium precipitation method (Chen \& Okayama 1987). For each $35 \mathrm{~mm}$ well of the six-well plates or $100 \mathrm{~mm}$ plates, $2 \mathrm{ml}$ media containing $4 \mu \mathrm{g}$ plasmid or $10 \mathrm{ml}$ media containing $20 \mu \mathrm{g}$ plasmid were added respectively. Cells were used for measuring ligand binding and agonist-stimulated cAMP generation 48 -h post-transfection as described below.

\section{Radioligand-binding assay with agonists}

The method for binding assay has been described in detail before (Tao \& Segaloff 2003). Briefly, $48 \mathrm{~h}$ after transfection, cells were washed twice with warm Waymouth's MB752/1 media (SigmaAldrich) modified to contain $1 \mathrm{mg} / \mathrm{ml}$ BSA (referred herein as Waymouth/BSA). One milliliter of fresh Waymouth/BSA with or without different concentrations of unlabeled agonists including $\alpha-, \gamma-$, NDP-, and D-Trp ${ }^{8}-\gamma-\mathrm{MSH}$ and 100000 c.p.m. of ${ }^{125}$ I-NDP-MSH $(50 \mu \mathrm{l})$ was added to each well. The final concentration of unlabeled ligands ranged from $10^{-10}$ to $10^{-5} \mathrm{M}$ (for $\alpha_{-}, \gamma-$, and D-Trp ${ }^{8}-\gamma-\mathrm{MSH}$ ) or from $10^{-11}$ to $10^{-6} \mathrm{M}$ (for NDP-MSH). After incubation at $37^{\circ} \mathrm{C}$ for $1 \mathrm{~h}$, cells were washed twice with cold Hanks' balanced salt solution (Sigma-Aldrich) modified to contain $1 \mathrm{mg} / \mathrm{ml}$ BSA (referred herein as HBSS/ BSA). Then, $100 \mu \mathrm{l}$ of $0.5 \mathrm{M} \mathrm{NaOH}$ were added to each well. Lysed cells were collected from each well using cotton swabs to plastic tubes, and ligand binding was counted in a $\gamma$-counter. All determinations were performed in duplicates. 
Radioligand-binding assay with $A g R P$

For AgRP-binding assay, transient transfection of plasmids was performed in $100 \mathrm{~mm}$ dishes as described above. Twenty-four hrs after transfection, cells were trypsinized, split into 24-well plates, and incubated for an additional $24 \mathrm{~h}$. Cells were washed twice with warm Waymouth/BSA. Fresh Waymouth/BSA containing $20 \mu \mathrm{l}$ of ${ }^{125}$ I-NDP-MSH (40 000 c.p.m.) and $20 \mu \mathrm{l}$ different concentrations (including zero) of unlabeled antagonist AgRP were added to each well to a total volume of $200 \mu \mathrm{l}$ per well. The final concentration of the unlabeled AgRP ranged from $10^{-11}$ to $10^{-6} \mathrm{M}$. After incubation at $37^{\circ} \mathrm{C}$ for $1 \mathrm{~h}$, cells were washed twice with cold HBSS/BSA. Then, $50 \mu$ l of $0.5 \mathrm{M}$ $\mathrm{NaOH}$ were added to each well. Cell lysate collection and ligand binding were performed as described above. All determinations were performed in triplicates.

\section{Intracellular $C A M P$ generation}

HEK293T cells were plated and transfected as described above. Forty-eight hours after transfection, cells were washed twice with warm Waymouth/BSA. Then, $1 \mathrm{ml}$ fresh Waymouth/BSA containing $0.5 \mathrm{mM}$ isobutylmethylxanthine (Sigma-Aldrich) was added to each well. After incubation at $37^{\circ} \mathrm{C}$ for $15 \mathrm{~min}$, either buffer alone or different concentrations of ligands (final concentrations of $10^{-11}-10^{-5} \mathrm{M}$ for $\alpha$ - and $\gamma$-MSH, and $10^{-12}-10^{-6} \mathrm{M}$ for NDP-MSH and D-Trp ${ }^{8}-\gamma-$ $\mathrm{MSH}$ ) were added, and the incubation was continued for an additional $1 \mathrm{~h}$. Cells were then placed on ice, media were aspirated, and intracellular cAMPs were extracted by the addition of $1.5 \mathrm{ml}$ fresh $0.5 \mathrm{M}$ perchloric acid containing $180 \mu \mathrm{g} / \mathrm{ml}$ theophylline, and measured using RIA. All determinations were performed in triplicate.

\section{Statistical analysis}

Maximal binding $\left(B_{\max }\right), \mathrm{IC}_{50}$, maximal responses $\left(R_{\max }\right)$, and $E_{50}$ were calculated using Prism 4.0 (GraphPad, San Diego, CA, USA). Data were presented as the mean and S.E.M. All statistical analyses were done using Prism 4.0.

\section{Results}

Nucleotide and deduced amino acid sequences of the putative $p M C 3 R$

Civanova et al. (2004) reported the partial sequence of the $\mathrm{pMC} 3 \mathrm{R}$ and mapped the $p M C 3 R$ gene to porcine chromosome 17. Recently, the complete nucleotide sequence of porcine chromosome 17 was deposited in GenBank. We performed nucleotide sequence alignment among the partial nucleotide sequence of $p M C 3 R$ gene (GenBank accession no. AJ744762), nucleotide sequence of the clone $\mathrm{CH} 242-$ 163M14 on porcine chromosome 17 (GenBank accession no. CR956393), and nucleotide sequences of human, rat, and mouse MC3Rs (GenBank accession nos. NM_019888,
NM_001025270, and NM_008561 respectively). We found that the putative $p M C 3 R$ gene was intronless and contained an open reading frame of $960 \mathrm{bp}$ encoding a putative protein of 319 amino acids (Fig. 1A). The TATA-box, characteristic of the mammalian promoter region, was identified $382 \mathrm{bp}$ upstream of the translation initiation site of the putative $\mathrm{pMC} 3 \mathrm{R}$; a potential poly $(\mathrm{A})^{+}$signal was recognized $1381 \mathrm{bp}$ downstream from the translation stop site of the putative pMC3R (highlighted in bold in Fig. 1A). Comparison of the putative pMC3R sequence with that of the MC3Rs from other species showed that pMC3R is $88 \cdot 2,85 \cdot 3$, and $86 \cdot 0 \%$ homologous at nucleotide level (Fig. 1B) and $87 \cdot 5,83 \cdot 1$, and $83 \cdot 7 \%$ identical at amino acid level (Fig. 2A and B) to human, mouse, and rat MC3Rs respectively. Further comparison indicated that $\mathrm{pMC} 3 \mathrm{R}$ is significantly conserved in amino acid sequence to other species in the TMDs, extracellular, and intracellular loops. But lower conservation is observed at the amino and carboxyl termini. In addition, the putative pMC3R is four amino acids shorter at the carboxyl terminus than human, rat, and mouse MC3Rs, and 37 amino acids shorter at the $\mathrm{N}$-terminus than human MC3R (but the same as that of rat and mouse MC3Rs). Phylogenetic analysis indicates that pMC3R clusters together with MC3Rs from other species at nucleotide level (Fig. 1C) but is significantly divergent from human MC3R and to a less degree from mouse and rat MC3Rs at amino acid level (Fig. 2C).

\section{Expression and functional analysis of the cloned $p M C 3 R$ in HEK293T cells}

Based on the sequence analysis described above, primers were designed and the $960 \mathrm{bp}$ of putative pMC3R was directly amplified from porcine genomic DNA by PCR and cloned into mammalian expression vector pcDNA3.1 for functional analysis. To demonstrate whether the cloned pMC3R is capable of producing a biologically active receptor protein, we transfected the pMC3R construct obtained into HEK293T cells and analyzed its ligand binding and signaling properties using the natural agonist for MC3R, $\gamma-\mathrm{MSH}$, and ligand-binding property with the natural antagonist for MC3R, AgRP. Human MC3R was used for comparison. As shown in Fig. 3 and Table 1, $\gamma$-MSH bound the cloned pMC3R with an $\mathrm{IC}_{50}$ of $129 \cdot 07 \mathrm{nM}$ and hMC3R with an $\mathrm{IC}_{50}$ of $293.00 \mathrm{nM}$. Both the cloned pMC3R and hMC3R bound AgRP with similar high affinity: the cloned pMC3R with an $\mathrm{IC}_{50}$ of $0.67 \mathrm{nM}$ and hMC3R with an $\mathrm{IC}_{50}$ of $2.35 \mathrm{nM}$. Furthermore, $\gamma$-MSH also induced dose-dependent accumulations of intracellular cAMP with $\mathrm{EC}_{50}$ of $79 \cdot 16$ and $111.13 \mathrm{nM}$ for the cloned pMC3R and hMC3R respectively. These results suggested that the cloned pMC3R encoded a functional MC3R protein.

\section{Binding and signaling of $p M C 3 R$ to three other $M C 3 R$ agonists}

For in vivo investigation of the role that $\mathrm{pMC} 3 \mathrm{R}$ plays in pigs, the most potent and selective agonist for pMC3R must be selected from the pool of known MC3R agonists. Herein, we tested the 


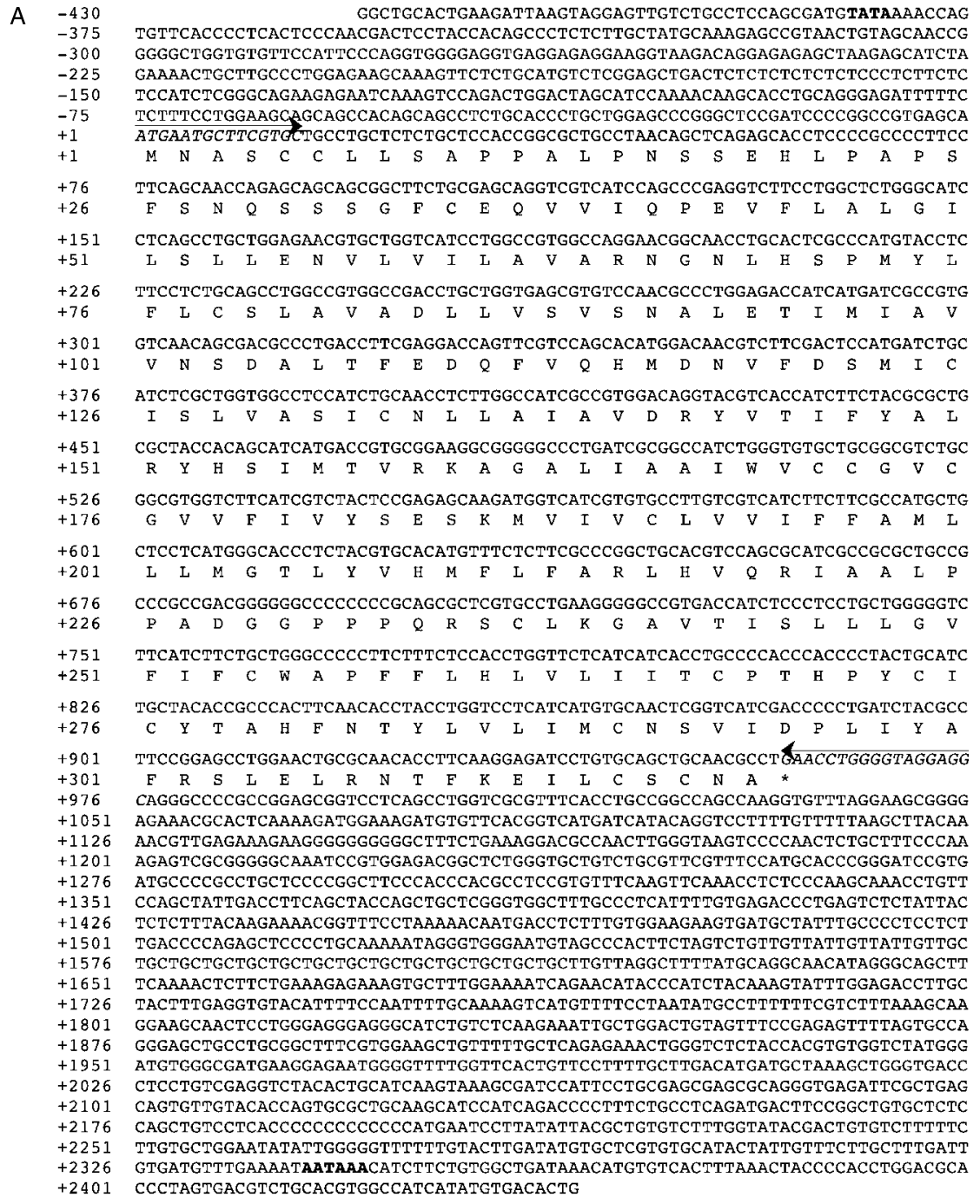

\begin{tabular}{lcccc}
\hline & Pig & Human & Mouse & Rat \\
\hline Pig & $100 \cdot 0$ & $88 \cdot 2$ & 85.3 & 86.0 \\
Human & & $100 \cdot 0$ & 87.6 & 87.6 \\
Mouse & & & 100.0 & 93.0 \\
Rat & & & & 100.0 \\
\hline
\end{tabular}

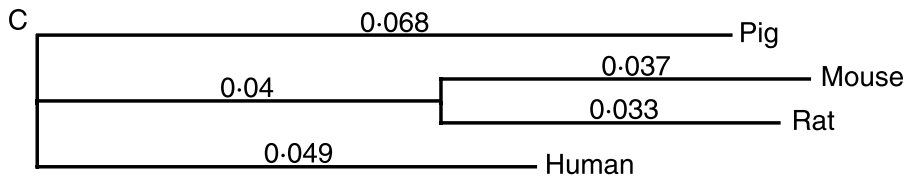

0.01

Figure 1 Deduced nucleotide and amino acid sequences of pMC3R and comparison with MC3Rs from other mammal. (A) Sequence of the full-length pMC3R cDNA with in silico translation is shown. Arrows indicate the position and direction of the primers used for amplification of the CDNA by PCR. (B) Homology and (C) phylogenetic analysis of MC3R nucleotide sequences from several species. 
PMC3R :

hMC3R:

mMC3R:

rMC3R :

PMC3R:

hMC3R:

mMC3R :

IMC3R:

PMC3R :

hMC3R :

mMC3R :

IMC3R:

PMC3R:

hMC3R :

mMC3R:

rMC3R :

PMC3R:

hMC3R:

mMC3R :

rMC3R:

PMC3R:

hMC3R:

MMC3R :

IMC3R:
Extracellular Amino Terminus

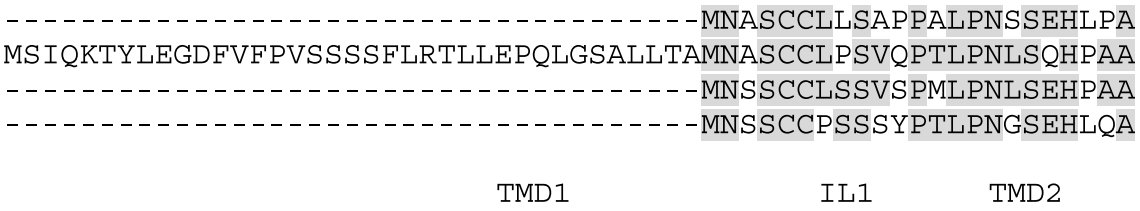

PSFSNQSSSGFCEQVVIQPEVFLALGILSLLENVLVILAVARNGNLHSPMYLFLCSLAVA PFFSNQSSSAFCEQVFIKPEVFLSLGIVSLLENILVILAVVRNGNLHSPMYFFLCSLAVA PPASNRSGSGFCEQVF IKPEVFLALGIVSLMENILVILAVVRNGNLHSPMYFFLCSLAAA PSASNRSGSGFCEQVF IKPEVFLALGIVSLMENILVILAVVRNGNLHSPMYFFLLSLLQA

EL1

TMD3

DLLVSVSNALETIMIAVVNSDALTFEDQFVQHMDNVFDSMICISLVASICNLLAIAVDRY DMLVSVSNALETIMIAIVHSDYLTFEDQF IQHMDNIFDSMICISLVAS ICNLLAIAVDRY DMLVSLSNSLETIMIAVINSDSLTLEDQF IQHMDNIFDSMICISLVASICNLLAIAIDRY DMLVSLSNSLETIMIVVINSDSLTLEDQF IQHMDNIFDSMICISLVAS ICNLLAIAVDRY

143 180 143 143
IL2
TMD4
EL2
TMD5

VTIFYALRYHS IMTVRKAGALIAAIWVCCGVCGVVF IVYSESKMVIVCLVVIFFAMLLLM VTIFYALRYHS IMTVRKALTLIVAIWVCCGVCGVVF IVYSESKMVIVCLITMFF AMMLLM VTIFYALRYHS IMTVRKALTLIGVIWVCCGICGVMF I IYSESKMVIVCLITMFFAMVLLM VTIFYALRYHS IMTVRKALSLIVAIWVCCGICGVMF IVYSESKMVIVCLITMFFAMVLLM

\section{IL3}

TMD 6

GTLYVHMFLFARLHVQRIAALPPADGGPPPQRSCLKGAVTISLLLGVF IFCWAPFFLHLV GTLYVHMFLFARLHVKRIAALPPADGVAPQQHSCMKGAVTITILLGVF IFCWAPF FLHLV GTLYIHMFLFARLHVQRIAVLPPAGVVAPQQHSCMKGAVTITILLGVF IFCWAPFFLHLV GTLYIHMFLFARLHVQR IAALPPADGVAPQQHSCMKGAVTITILLGVF IFCWAPFFLHLV

Cytoplasmic Tail

LIITCPTHPYCICYTAHFNTYLVLIMCNSVIDPLIYAFRSLELRNTFKEILCSCNA - - LIITCPTNPYCICYTAHFNTYLVLIMCNSVIDPLIYAFRSLELRNTFREILCGCNGMNLG LIITCPTNPYCICYTAHFNTYLVLIMCNSVIDPLIYAFRSLELRNTFKEILCGCNSMNLG LIITCPTNPYCICYTAHFNTYLVLIMCNSVIDPLIYAFRSLELRNTFKEILCGCNGMNVG

\begin{tabular}{lcccc}
\hline & Pig & Human & Mouse & Rat \\
\hline Pig & 100.0 & 87.5 & 83.1 & 83.7 \\
Human & & 100.0 & 88.7 & 89.3 \\
Mouse & & & 100.0 & 94.0 \\
Rat & & & & 100.0 \\
\hline
\end{tabular}

C


Figure 2 Comparison of amino acid sequences between pMC3R and MC3Rs from other species. Alignment of the amino acid sequences between pMC3R and human, mouse and rat MC3Rs. Positions of different regions of the receptor are indicated above the sequences and labeled as follows: transmembrane domains as TMD 1-7, extracellular loops as EL 1-3, intracellular loops as IL 1-3, amino and carboxyl termini as extracellular amino terminus and cytoplasmic tail respectively. The conserved residues are shaded in gray. The transmembrane residues are in bold. (B) Homology and (C) phylogenetic analysis of MC3R amino acid sequences from several species. 

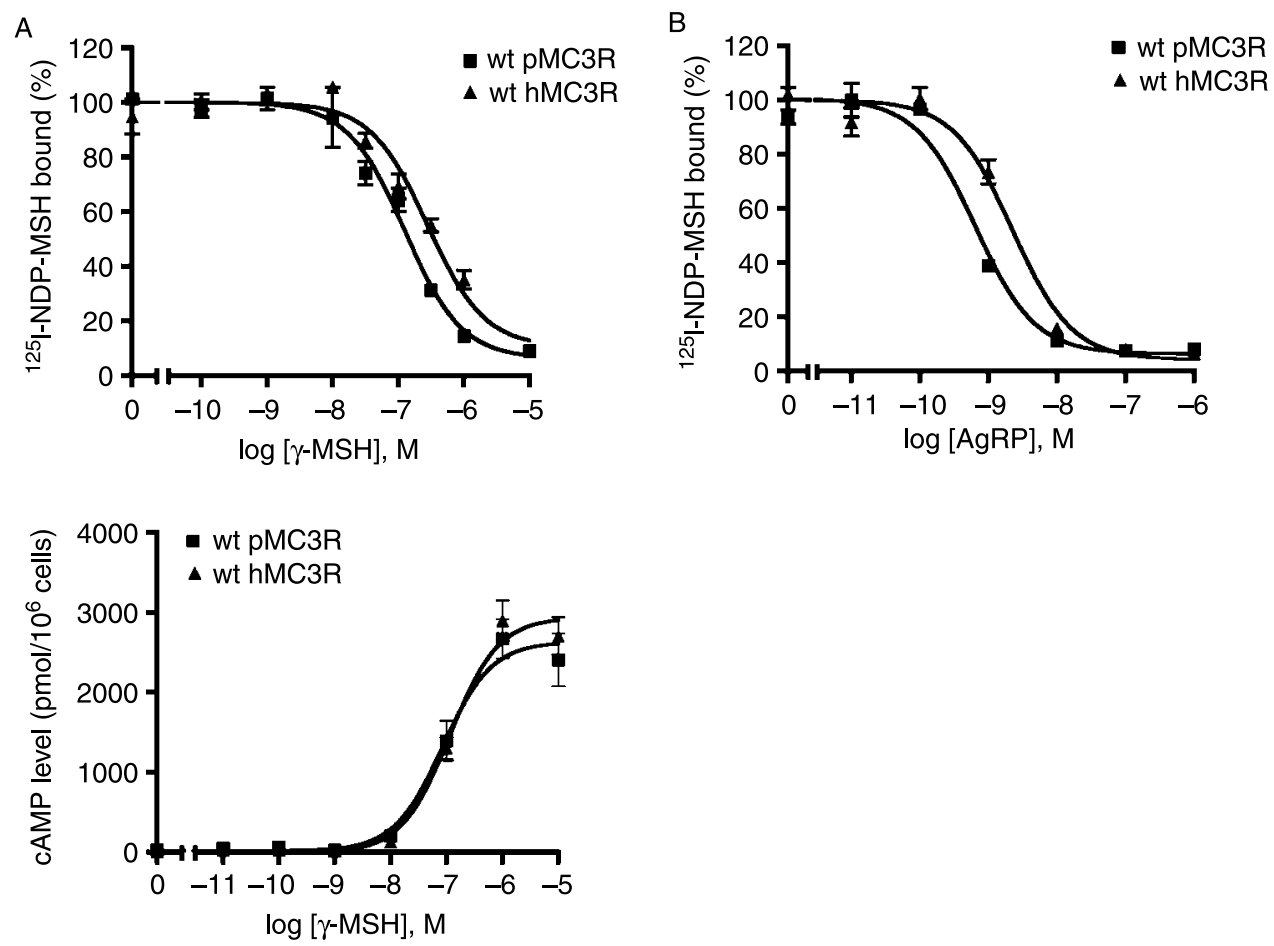

Figure 3 Expression and functional analysis of the cloned pMC3R in HEK293T cells. HEK293T cells were transiently transfected with $\mathrm{pMC} 3 \mathrm{R}$ and $\mathrm{hMC} 3 \mathrm{R}$, and binding and signaling assays were performed as described in Materials and Methods. For ligand binding, different concentrations of unlabeled (A) $\gamma-\mathrm{MSH}$ or (B) AgRP were used to displace the binding of ${ }^{125} \mathrm{I}$-NDP-MSH to $\mathrm{pMC} 3 \mathrm{R}$ or hMC3R on intact cells. Results shown are expressed as the percentage \pm S.E.M. of the maximal binding from duplicate determinations within one experiment. All experiments were performed at least thrice. For measurement of cAMP accumulation, the transfected cells were stimulated with various concentrations of $\gamma-\mathrm{MSH}$, and intracellular cAMP levels were measured as described in Materials and Methods. Results are expressed as the mean \pm s.E.M. of triplicate determinations within one experiment, and all experiments were performed at least thrice.

pharmacological properties of three MC3R agonists on the cloned pMC3R. These agonists include the natural agonist of MC3R, $\alpha-M S H$; a superpotent analog of $\alpha$-MSH for MC3R and MC4R, NDP-MSH; and a superpotent analog specific for
MC3R, D-Trp ${ }^{8}-\gamma-\mathrm{MSH}$. As shown in Fig. 4, ligand-binding assays revealed that pMC3R bound NDP-MSH with the highest affinity $\left(\mathrm{IC}_{50}\right.$ of $\left.4.36 \mathrm{nM}\right)$ followed by D-Trp ${ }^{8}-\gamma-\mathrm{MSH}$ $\left(\mathrm{IC}_{50}\right.$ of $\left.10.65 \mathrm{nM}\right)$ and $\alpha-\mathrm{MSH}\left(\mathrm{IC}_{50}\right.$ of $\left.674.90 \mathrm{nM}\right)$. The same

Table 1 Ligand binding and agonist-stimulated cAMP response of porcine melanocortin-3 receptor (pMC3R) and human MC3R (hMC3R). Data shown are the mean \pm S.E.M. of the indicated number of experiments

\begin{tabular}{|c|c|c|c|c|c|c|}
\hline & \multirow[b]{2}{*}{ MC3R } & \multirow[b]{2}{*}{$n$} & \multirow{2}{*}{$\begin{array}{l}\text { Ligand binding } \\
\mathrm{IC}_{50}(\mathrm{nM})\end{array}$} & \multirow[b]{2}{*}{$n$} & \multicolumn{2}{|c|}{ Ligand-stimulated cAMP response } \\
\hline & & & & & $\mathrm{EC}_{50}(\mathrm{nM})$ & Rmax (pmol/ $10^{6}$ cells $)$ \\
\hline \multicolumn{7}{|l|}{ Ligands } \\
\hline \multirow[t]{2}{*}{$\alpha-\mathrm{MSH}$} & Porcine & 3 & $674 \cdot 90 \pm 83 \cdot 76$ & 4 & $59 \cdot 03 \pm 7 \cdot 51$ & $2854 \pm 96$ \\
\hline & Human & 3 & $1151 \cdot 33 \pm 85 \cdot 54$ & 4 & $70 \cdot 27 \pm 11 \cdot 97$ & $2765 \pm 238$ \\
\hline \multirow[t]{2}{*}{ NDP-MSH } & Porcine & 5 & $4 \cdot 36 \pm 0 \cdot 43$ & 4 & $2 \cdot 24 \pm 0 \cdot 24$ & $1286 \pm 160$ \\
\hline & Human & 5 & $21 \cdot 71 \pm 2 \cdot 64$ & 4 & $5 \cdot 01 \pm 0 \cdot 87$ & $2438 \pm 333$ \\
\hline \multirow[t]{2}{*}{$\gamma-\mathrm{MSH}$} & Porcine & 3 & $129 \cdot 07 \pm 3 \cdot 28$ & 4 & $79 \cdot 16 \pm 6 \cdot 05$ & $2354 \pm 147$ \\
\hline & Human & 3 & $293 \cdot 00 \pm 21 \cdot 64$ & 4 & $111 \cdot 13 \pm 11 \cdot 78$ & $2623 \pm 185$ \\
\hline \multirow[t]{2}{*}{$\mathrm{D}-\mathrm{Trp}^{8}-\gamma-\mathrm{MSH}$} & Porcine & 3 & $10 \cdot 65 \pm 3 \cdot 31$ & 4 & $1 \cdot 24 \pm 0 \cdot 58$ & $1894 \pm 256$ \\
\hline & Human & 3 & $90 \cdot 74 \pm 12 \cdot 46$ & 4 & $1.95 \pm 0.64$ & $1972 \pm 258$ \\
\hline \multirow[t]{2}{*}{ AgRP } & Porcine & 3 & $0 \cdot 67 \pm 0 \cdot 06$ & NA & $\mathrm{NA}$ & $\mathrm{NA}$ \\
\hline & Human & 3 & $2 \cdot 35 \pm 0 \cdot 42$ & NA & NA & NA \\
\hline
\end{tabular}

$\mathrm{IC}_{50}$ is the concentration of ligand that is needed to cause $50 \%$ inhibition in the binding assay. $\mathrm{EC}_{50}$ is the concentration of agonist that results in $50 \%$ stimulation of the maximal response. NA, not applicable. 
A
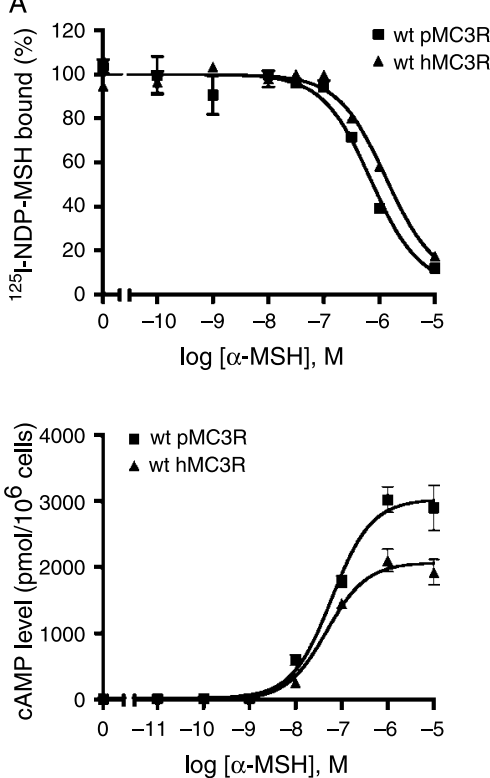

B
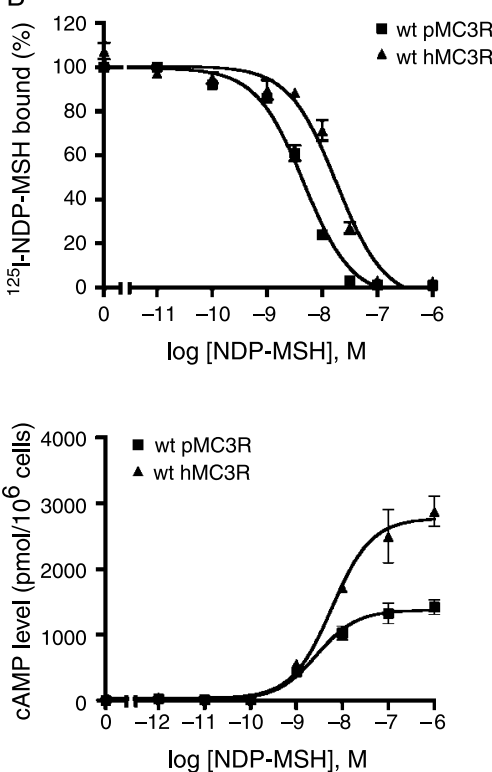

C
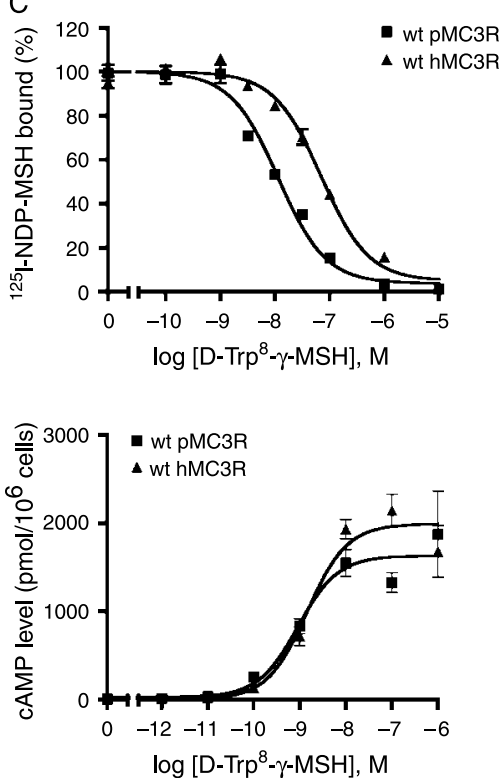

Figure 4 Binding and signaling of pMC3R to three other MC3R agonists. HEK293T cells were transiently transfected with pMC3R or hMC3R. Binding assays were performed as described in Materials and methods. Different concentrations of unlabeled (A) $\alpha-\mathrm{MSH}$, (B) NDP-MSH, or (C) D-Trp ${ }^{8}-\gamma-\mathrm{MSH}$ were used to displace the binding of ${ }^{125} \mathrm{I}-\mathrm{NDP}-\mathrm{MSH}$ to pMC3R or hMC3R on intact cells. To measure accumulation of intracellular cAMP, the transfected cells were stimulated with various concentrations of (A) $\alpha-M S H,(B) N D P-M S H, o r(C) D-T r p{ }^{8}-\gamma-M S H$, and intracellular CAMP levels were measured as described in Materials and methods. Results are expressed as the mean \pm S.E.M. of triplicate determinations within one experiment, and all experiments were performed at least thrice.

ranking was also observed for $\mathrm{hMC} 3 \mathrm{R}$ with an $\mathrm{IC}_{50}$ of 21.71 nM for NDP-MSH, $90 \cdot 74 \mathrm{nM}$ for D-Trp ${ }^{8}-\gamma-\mathrm{MSH}$, and $1151 \cdot 33 \mathrm{nM}$ for $\boldsymbol{\alpha}-\mathrm{MSH}$. It is interesting to note that pMC3R always had two- to ninefold higher affinities for these ligands than the hMC3R (Table 1). The data from the signaling assays demonstrated that $\mathrm{D}-\operatorname{Trp}^{8}-\gamma-\mathrm{MSH}$ was the most potent agonist to stimulate dose-dependent cAMP generation with an $\mathrm{EC}_{50}$ of $1 \cdot 24 \mathrm{nM}$, followed by NDP-MSH $\left(\mathrm{EC}_{50}\right.$ of $\left.2 \cdot 24 \mathrm{nM}\right)$ and $\boldsymbol{\alpha}$-MSH (EC Ef of 59.03 nM; Table 1). Human MC3R has the same ranking with an $\mathrm{EC}_{50}$ of $1.95 \mathrm{nM}$ for $\mathrm{D}-\operatorname{Trp}^{8}-\gamma-\mathrm{MSH}$, 5.01 nM for NDP-MSH, and 70.27 nM for $\alpha-M S H$ (Table 1). Taken together, these data demonstrated that $\mathrm{D}-\operatorname{Trp}^{8}-\gamma-\mathrm{MSH}$ was the most potent agonist in eliciting pMC3R signaling.

As can be seen from Table 1, the maximal responses to $\alpha-$, $\gamma-$, and $\mathrm{D}-\operatorname{Trp}^{8}-\gamma-\mathrm{MSH}$ are similar between the pMC3R and hMC3R. However, the hMC3R has significantly larger maximal response to NDP-MSH than pMC3R. One reason might be that hMC3R is expressed at slightly higher level $(148 \pm 8 \%$ of $\mathrm{pMC} 3 \mathrm{R}, n=12)$. However, the maximal responses to the other three agonists are similar between the two MC3Rs. We suggest that the NDP-MSH binding to hMC3R induces a conformation with higher coupling efficiency than the pMC3R (Ballesteros et al. 1998).

\section{Discussion}

Previous pharmacological and genetic studies in rodents suggested that the MC3R was not involved in food intake regulation. Administration of MC3R-specific agonist such as $\gamma$-MSH did not inhibit food intake (Kask et al. 2000). In fact, a recent study showed that peripheral administration of D-Trp ${ }^{8}$ $\gamma$-MSH stimulated food intake in rats by releasing the inhibitory effect of the MC3R on POMC neurons (Marks et al. 2006). Changes in energy balance such as food restriction or dietinduced obesity did not change MC3R expression level in the brain, whereas the MC4R density was modulated (Harrold et al. 1999). Finally, MC3R knockout mice did not have increased food intake as did the MC4R knockout mice (Huszar et al. 1997, Butler et al. 2000, Chen et al. 2000). Mice lacking the MC3R have increased fat contents but are normal in terms offood intake and body weight (Butler et al. 2000, Chen et al. 2000), suggesting that the MC3R pathway modulates feeding efficiency and fat storage. The recent gene targeting study by Zhang et al. (2005) showed that Black Swiss 129 mice lacking MC3R gene had a comparable level of adiposity as mice lacking the $M C 4 R$ gene. In humans, only a few naturally occurring mutations in the MC3R gene have been identified (Lee et al. 2002, 2007, Tao 2007). These mutations were found to cause defects in signaling (Rached et al. 2004, Tao \& Segaloff 2004, Lee et al. 2007, Tao 2007). In contrast, in the MC4R, numerous mutations have been identified from various patient populations (reviewed in Tao 2005, 2006). Therefore, the roles of the MC3R in energy homeostasis are much less understood.

Pork is an important protein source in our diet. About $60 \%$ of the saturated fat comes from animal products in typical American diet. Leaner meat will decrease intake of saturated 
fat and decrease blood cholesterol levels. To increase the economic return for hog farmers and reduce the obesity epidemic, it is of great interest to decrease the fat content in pork. Therefore, a better understanding of fat storage in pigs is of great economic interest.

In the present study, as the first step towards elucidating the role(s) of the MC3R in pig energy homeostasis, we describe the molecular cloning and pharmacological characterization of the porcine MC3R. Through bioinformatics analysis and progress in pig genome sequencing, we were able to identify the putative full-length coding region of pMC3R. Primers designed based on this sequence were used to amplify the coding region from pig genomic DNA by taking advantage of the fact that the mammalian MCRs, including the putative $\mathrm{pMC} 3 \mathrm{R}$, are intronless. This amplified fragment was inserted into pcDNA3.1 and the sequence verified.

This construct was used for detailed pharmacological analysis using a series of ligands. From ligand-binding studies, we showed that of the four agonists tested, the rank order in terms of affinity is: NDP-MSH $>$ D-Trp ${ }^{8}-\gamma-\mathrm{MSH}>\gamma$ MSH $>\alpha-M S H$. Human MC3R has the same rank order for these ligands. From signaling experiments, we showed that the rank order in terms of potency for these four ligands is: D- $\operatorname{Trp}^{8}-\gamma-\mathrm{MSH}>\mathrm{NDP}-\mathrm{MSH}>\boldsymbol{\alpha - \mathrm { MSH }}>\boldsymbol{\gamma}-\mathrm{MSH}$. Again, $\mathrm{hMC} 3 \mathrm{R}$ has the same rank order for these ligands. Both pMC3R and hMC3R bind to AgRP with high affinity, with $\mathrm{IC}_{50}$ of 0.67 and $2.35 \mathrm{nM}$ respectively.

Previously, the MC3Rs have been cloned from a number of species, including human (Gantz et al. 1993a), rat (Roselli-Rehfuss et al. 1993), mouse (Desarnaud et al. 1994), and elephant (Rompler et al. 2006). In lower vertebrates, the MC3Rs have been cloned from the chicken (Takeuchi \& Takahashi 1999) and zebrafish (Logan et al. 2003) but was found to be absent in some other fishes such as the pufferfishes (Klovins et al. 2004a). The numbers we reported herein for pMC3R are roughly in line with previous studies. For example, with NDP-MSH, the most commonly used analog for MCR studies, the $\mathrm{IC}_{50}$ reported here for $\mathrm{pMC} 3 \mathrm{R}$ is $4.36 \mathrm{nM}$. Previously, the $K_{\mathrm{d}}$ for rat MC3R was reported to be $3.78 \mathrm{nM}$ (Kim et al. 2002), and the Ki for human MC3R was $5.6 \mathrm{nM}$ (Chen et al. 2006), and for the dogfish MC3R was $0.93 \mathrm{nM}$ (Klovins et al. 2004b).

In the original publication describing the discovery of D- $\operatorname{Trp}^{8}-\gamma-\mathrm{MSH}$ as a potent and selective MC3R agonist (Grieco et al. 2000), an $\mathrm{IC}_{50}$ of $6.7 \mathrm{nM}$ and $\mathrm{EC}_{50}$ of $0.33 \mathrm{nM}$ were reported for hMC3R. Our data for hMC3R are somewhat higher than those reported before $\left(\mathrm{IC}_{50}\right.$ of $90.74 \mathrm{nM}$ and $\mathrm{EC}_{50}$ of $1.95 \mathrm{nM}$ ). These differences might be due to the use of different cell lines and different methods in the two studies. For example, for binding studies, Grieco et al. used membranes prepared from L cells stably expressing hMC3R, whereas we used live HEK293T cells transiently expressing hMC3R (only cell surface receptor binding is detected). However, our data for $\mathrm{pMC} 3 \mathrm{R}$ ( $\mathrm{IC}_{50}$ of $10.65 \mathrm{nM}$ and $\mathrm{EC}_{50}$ of $1.24 \mathrm{nM}$ ) are very close to the numbers reported for hMC3R by Grieco et al. (2000).
It should be pointed out that the ranking in terms of affinity is not the same as that in terms of potency. For example, for pMC3R, NDP-MSH has higher binding affinity than $\mathrm{D}-\operatorname{Trp}^{8}-\gamma-\mathrm{MSH}$. However, it is not as potent in eliciting activation of signaling pathways as the latter. This may be due to the difference in their relative efficacies. Both affinity and efficacy can independently affect the potency of a particular ligand (Besse \& Furchgott 1976).

The data presented herein suggest that $\mathrm{D}-\operatorname{Trp}^{8}-\gamma-\mathrm{MSH}$ is a superpotent agonist for the pMC3R. Since it does not activate the MC4R efficiently (Grieco et al. 2000), it is an excellent tool for in vivo studies directed towards dissecting the role(s) of the MC3R in regulating pig energy balance. However, the in vitro data described herein should only be used as the starting point for further in vivo studies. Previous studies showed that pMC4Rs respond to the natural (AgRP) and artificial (SHU9119) antagonists normally in vitro. However, in vivo, these antagonists do not increase food intake as observed in rodents (Barb et al. 2004). It was suggested that the MC4R might not play a critical role in regulating feed intake in the pig (Barb et al. 2004). Similarly, two naturally occurring mutations (R236H and D298N) in the pMC4R were identified in different strains of pigs that are associated with differences in performance characteristics such as average daily gain and average daily intake as well as carcass fat (Kim et al. 2000, Meidtner et al. 2006). In the case of D298N, not all studies could confirm the original associations (Park et al. 2002, Stachowiak et al. 2006). Similarly, our experiments in vitro could not replicate the original functional studies (Kim et al. 2004, Fan et al. 2007). Therefore, the data on the naturally occurring mutations in the pMC4R are also much less convincing than those on human MC4R (reviewed in Tao $(2005,2006))$. All these point to the importance of using caution when extrapolating in vitro data as well as the potential difference of the relevance of the melanocortin system in regulating energy homeostasis in the pig.

In summary, we have cloned the pMC3R. Expression of the cloned pMC3R in HEK293T cells revealed that indeed it was functional. Pharmacological characterizations using a series of ligands revealed that the pMC3R and hMC3R have the same rank orders for these ligands. We showed that D-Trp ${ }^{8}-\gamma-\mathrm{MSH}$ was the most potent ligand (and selective for the MC3R), therefore, best suited for further in vivo studies to elucidate the functional importance of the MC3R in energy homeostasis in the pig.

\section{Acknowledgements}

We thank Dr Ira Gantz (previously at University of Michigan, Ann Arbor, MI, USA) for generously providing us the human MC3R cDNA. This study was supported by a Foundation Grant from Alabama Agricultural Experiment Station (ALA080-031). The authors declare that there is no conflict of interest that would prejudice the impartiality of this scientific work. 


\section{References}

Ballesteros J, Kitanovic S, Guarnieri F, Davies P, Fromme BJ, Konvicka K, Chi L, Millar RP, Davidson JS, Weinstein H et al. 1998 Functional microdomains in G-protein-coupled receptors. The conserved arginine-cage motif in the gonadotropin-releasing hormone receptor. Journal of Biological Chemistry 273 10445-10453.

Barb CR, Robertson AS, Barrett JB, Kraeling RR \& Houseknecht KL 2004 The role of melanocortin-3 and -4 receptor in regulating appetite, energy homeostasis and neuroendocrine function in the pig. Journal of Endocrinology $18139-52$.

Besse JC \& Furchgott RF 1976 Dissociation constants and relative efficacies of agonists acting on alpha adrenergic receptors in rabbit aorta. Journal of Pharmacology and Experimental Therapeutics 197 66-78.

Butler AA, Kesterson RA, Khong K, Cullen MJ, Pelleymounter MA, Dekoning J, Baetscher M \& Cone RD 2000 A unique metabolic syndrome causes obesity in the melanocortin-3 receptor-deficient mouse. Endocrinology $1413518-3521$.

Chen C \& Okayama H 1987 High-efficiency transformation of mammalian cells by plasmid DNA. Molecular and Cellular Biology 7 2745-2752.

Chen AS, Marsh DJ, Trumbauer ME, Frazier EG, Guan XM, Yu H, Rosenblum CI, Vongs A, Feng Y, Cao L et al. 2000 Inactivation of the mouse melanocortin-3 receptor results in increased fat mass and reduced lean body mass. Nature Genetics 26 97-102.

Chen M, Aprahamian CJ, Celik A, Georgeson KE, Garvey WT, Harmon CM \& Yang Y 2006 Molecular characterization of human melanocortin-3 receptor ligand-receptor interaction. Biochemistry 45 1128-1137.

Civanova K, Knoll A, Rohrer GA \& Cepica S 2004 Linkage mapping of the MC3R gene to porcine chromosome 17. Animal Genetics 35 467-469.

Cone RD 2005 Anatomy and regulation of the central melanocortin system. Nature Neuroscience 8 571-578.

Desarnaud F, Labbe O, Eggerickx D, Vassart G \& Parmentier M 1994 Molecular cloning, functional expression and pharmacological characterization of a mouse melanocortin receptor gene. Biochemical Journal 299 367-373.

Fan ZC, Sartin JL \& Tao YX 2007 Pharmacological analysis of two naturally occurring porcine melanocortin-4 receptor mutations in domestic pigs. Domestic Animal Endocrinology. In press.

Gantz I \& Fong TM 2003 The melanocortin system. American Journal of Physiology 284 E468-E474.

Gantz I, Konda Y, Tashiro T, Shimoto Y, Miwa H, Munzert G, Watson SJ, DelValle J \& Yamada T 1993a Molecular cloning of a novel melanocortin receptor. Journal of Biological Chemistry 268 8246-8250.

Gantz I, Miwa H, Konda Y, Shimoto Y, Tashiro T, Watson SJ, DelValle J \& Yamada T 1993b Molecular cloning, expression, and gene localization of a fourth melanocortin receptor. Journal of Biological Chemistry 268 15174-15179.

Getting SJ, Gibbs L, Clark AJ, Flower RJ \& Perretti M 1999 POMC genederived peptides activate melanocortin type 3 receptor on murine macrophages, suppress cytokine release, and inhibit neutrophil migration in acute experimental inflammation. Journal of Immunology 162 7446-7453.

Grieco P, Balse PM, Weinberg D, MacNeil T \& Hruby VJ 2000 D-Amino acid scan of $\gamma$-melanocyte-stimulating hormone: importance of Trp8 on human MC3 receptor selectivity. Journal of Medicinal Chemistry 43 4998-5002.

Harrold JA, Widdowson PS \& Williams G 1999 Altered energy balance causes selective changes in melanocortin-4 (MC4-R), but not melanocortin-3 (MC3-R), receptors in specific hypothalamic regions: further evidence that activation of MC4-R is a physiological inhibitor offeeding. Diabetes 48 267-271.

Huszar D, Lynch CA, Fairchild-Huntress V, Dunmore JH, Fang Q, Berkemeier LR, Gu W, Kesterson RA, Boston BA, Cone RD et al. 1997 Targeted disruption of the melanocortin-4 receptor results in obesity in mice. Cell 88 131-141.

Kask A, Rago L, Wikberg JE \& Schioth HB 2000 Differential effects of melanocortin peptides on ingestive behaviour in rats: evidence against the involvement of $\mathrm{MC}(3)$ receptor in the regulation of food intake. Neuroscience Letters 283 1-4.

Kim KS, Larsen N, Short T, Plastow G \& Rothschild MF 2000 A missense variant of the porcine melanocortin-4 receptor (MC4R) gene is associated with fatness, growth, and feed intake traits. Mammalian Genome 11 131-135.
Kim CS, Lee SH, Kim RY, Kim BJ, Li SZ, Lee IH, Lee EJ, Lim SK, Bae YS, Lee $\mathrm{W}$ et al. 2002 Identification of domains directing specificity of coupling to G-proteins for the melanocortin MC3 and MC4 receptors. Journal of Biological Chemistry 277 31310-31317.

Kim KS, Reecy JM, Hsu WH, Anderson LL \& Rothschild MF 2004 Functional and phylogenetic analyses of a melanocortin-4 receptor mutation in domestic pigs. Domestic Animal Endocrinology 26 75-86.

Klovins J, Haitina T, Fridmanis D, Kilianova Z, Kapa I, Fredriksson R, Gallo-Payet N \& Schioth HB 2004a The melanocortin system in Fugu: determination of POMC/AGRP/MCR gene repertoire and synteny, as well as pharmacology and anatomical distribution of the MCRs. Molecular Biology and Evolution 21 563-579.

Klovins J, Haitina T, Ringholm A, Lowgren M, Fridmanis D, Slaidina M, Stier S \& Schioth HB 2004b Cloning of two melanocortin (MC) receptors in spiny dogfish: MC3 receptor in cartilaginous fish shows high affinity to ACTHderived peptides while it has lower preference to gamma-MSH. European Journal of Biochemistry 271 4320-4331.

Lee YS, Poh LK \& Loke KY 2002 A novel melanocortin 3 receptor gene (MC3R) mutation associated with severe obesity. Journal of Clinical Endocrinology and Metabolism 87 1423-1426.

Lee YS, Poh LK, Kek BL \& Loke KY 2007 The role of melanocortin 3 receptor gene in childhood obesity. Diabetes 56 2622-2630.

Logan DW, Bryson-Richardson RJ, Taylor MS, Currie P \& Jackson IJ 2003 Sequence characterization of teleost fish melanocortin receptors. Annals of the New York Academy of Sciences 994 319-330.

Marks DL, Hruby V, Brookhart G \& Cone RD 2006 The regulation of food intake by selective stimulation of the type 3 melanocortin receptor (MC3R). Peptides 27 259-264.

Meidtner K, Wermter AK, Hinney A, Remschmidt H, Hebebrand J \& Fries R 2006 Association of the melanocortin 4 receptor with feed intake and daily gain in F2 Mangalitsa $\times$ Pietrain pigs. Animal Genetics 37 245-247.

Mountjoy KG, Mortrud MT, Low MJ, Simerly RB \& Cone RD 1994 Localization of the melanocortin-4 receptor (MC4-R) in neuroendocrine and autonomic control circuits in the brain. Molecular Endocrinology 8 1298-1308.

Park HB, Carlborg O, Marklund S \& Andersson L 2002 Melanocortin-4 receptor (MC4R) genotypes have no major effect on fatness in a Large White $\times$ Wild Boar intercross. Animal Genetics 33 155-157.

Rached M, Buronfosse A, Begeot M \& Penhoat A 2004 Inactivation and intracellular retention of the human I183N mutated melanocortin 3 receptor associated with obesity. Biochimica et Biophysica Acta 1689 229-234.

Rompler H, Rohland N, Lalueza-Fox C, Willerslev E, Kuznetsova T, Rabeder G, Bertranpetit J, Schoneberg T \& Hofreiter M 2006 Nuclear gene indicates coat-color polymorphism in mammoths. Science 31362.

Roselli-Rehfuss L, Mountjoy KG, Robbins LS, Mortrud MT, Low MJ, Tatro JB, Entwistle ML, Simerly RB \& Cone RD 1993 Identification of a receptor for $\gamma$ melanotropin and other proopiomelanocortin peptides in the hypothalamus and limbic system. PNAS 90 8856-8860.

Sawyer TK, Sanfilippo PJ, Hruby VJ, Engel MH, Heward CB, Burnett JB \& Hadley ME 1980 4-Norleucine, 7-D-phenylalanine- $\alpha$-melanocyte-stimulating hormone: a highly potent $\alpha$-melanotropin with ultralong biological activity. PNAS 77 5754-5758.

Smith AI \& Funder JW 1988 Proopiomelanocortin processing in the pituitary, central nervous system, and peripheral tissues. Endocrine Reviews 9 159-179.

Stachowiak M, Szydlowski M, Obarzanek-Fojt M \& Switonski M 2006 An effect of a missense mutation in the porcine melanocortin-4 receptor (MC4R) gene on production traits in Polish pig breeds is doubtful. Animal Genetics 37 55-57.

Takeuchi S \& Takahashi S 1999 A possible involvement of melanocortin 3 receptor in the regulation of adrenal gland function in the chicken. Biochimica et Biophysica Acta 1448 512-518.

Tao YX 2005 Molecular mechanisms of the neural melanocortin receptor dysfunction in severe early onset obesity. Molecular and Cellular Endocrinology $2391-14$.

Tao YX 2006 Inactivating mutations of G protein-coupled receptors and diseases: structure-function insights and therapeutic implications. Pharmacology and Therapeutics $111949-973$. 
Tao YX 2007 Functional characterization of novel melanocortin-3 receptor mutations identified from obese subjects. Biochimica et Biophysica Acta 1772 1167-1174.

Tao YX \& Segaloff DL 2003 Functional characterization of melanocortin-4 receptor mutations associated with childhood obesity. Endocrinology 144 4544-4551.

Tao YX \& Segaloff DL 2004 Functional characterization of melanocortin-3 receptor variants identify a loss-of-function mutation involving an amino acid critical for $\mathrm{G}$ protein-coupled receptor activation. Journal of Clinical Endocrinology and Metabolism 89 3936-3942.

Zhang Y, Kilroy GE, Henagan TM, Prpic-Uhing V, Richards WG, Bannon AW, Mynatt RL \& Gettys TW 2005 Targeted deletion of melanocortin receptor subtypes 3 and 4, but not CART, alters nutrient partitioning and compromises behavioral and metabolic responses to leptin. FASEB Journal 19 1482-1491.

Received in final form 3 October 2007

Accepted 15 October 2007

Made available online as an Accepted Preprint 15 October 2007 